\title{
2
}

\section{Categorical Dissonance: Experiencing Gavman at the Frieda River Project in Papua New Guinea}

\author{
Emilia E. Skrzypek
}

\section{Introduction}

Much of the thinking about roles and responsibilities in resource extraction projects is framed around the notion of stakeholder categories. These categories group people of a given type under a particular label, and award them with prescriptive roles and responsibilities. Like many countries around the world, in Papua New Guinea (PNG) provisions in national legislation make the state the owner of the country's mineral resources and the regulator of the extractive sector. In order to capitalise on these resources, the government enters into agreements with mining companies, which have the financial and technological capacity to operate resource extraction projects, and the host area communities who claim customary ownership over the land. The country's first large-scale mining project, the Panguna mine on the island of Bougainville, began its operations in 1972, with the Ok Tedi mine in the country's Western Province following 12 years later. In the 1980s and 1990s respectively, the two mines were sites of dramatic events that sent shockwaves through the sector. A breakdown of social relations at Panguna resulted in an armed conflict, claiming thousands of lives (May and Spriggs 1990), while mismanagement at the Ok Tedi mine led to a natural disaster and 
one of the most famous legal challenges in the history of the industry (Banks and Ballard 1997). The legacy of those events forced governments and companies in and beyond PNG to acknowledge landowners as the third key stakeholder category in resource extraction projects (Imbun 2007), where stakeholders are defined as 'groups and individuals who can affect, or are affected by, the achievement of an organisation's missions' (Freeman 2010 [1984]: 48). ${ }^{1}$ This triad model, which recognises the state, the company and local communities as the three key stakeholder groups, continues to serve as a 'provisional analytical device' (Ballard and Banks 2003: 289) in industry as well as academia, amid mounting acknowledgement that 'it has not generally served to capture much of the complexity of the relationships that form around mining as a site' (ibid.).

As the sense of a mining community broadened, the significance of additional stakeholders such as NGOs, media, legal agencies and global financial institutions rapidly expanded, forming what Ballard and Banks (2003: 304) glossed 'the fourth estate'-included in resource relations 'by virtue of connections to or alliances with (rather than membership of) one of the three principal stakeholder categories'. More recently, Filer and Le Meur proposed extending the triad model to include the fourth element, which they called 'society'. They also reframed the original three stakeholder categories as spaces rather than conceptual entities and argued that:

there is no large-scale mining project that involves just one company, one government agency or even one mine-affected community. Instead, there is a corporate space, a government space and a community space, each of which is liable to be occupied by a number of organisations or agencies in different relationships with each other, some of which count as political relationships, and within each of these organisations or agencies there are more political relationships. (2017: 22)

This view is reflective of a growing recognition in the anthropology of mining that, held too tightly, categories can hinder rather than aid our understanding of complexities of stakeholder engagement in resource extraction projects. Instead, the discipline has turned much of its focus to nuanced processes and enactments of categories as they are taking place, in project locations (e.g. Golub 2014; Welker 2014). Inevitably, the closer

1 This development was then reflected in the establishment of the Development Forum process for the Porgera mine-PNG's next major development project (Filer 2008). 
we get to the ambiguities and complexities of on-the-ground relations, the more distant and blurry the categorical prescriptions become. Yet, it would be dangerous to neglect categorical prescriptions from any systematic analysis, as they frame and influence on-the-ground interactions and are indispensable to our understanding of 'stakeholder relations'. Here, I focus on the contested spaces in between stakeholder categories and their enactments in the project location. Categorical models tend to make assumptions about what the latter ought to look like. They often contain specific instructions to facilitate types of interactions and relations (e.g. through legal frameworks, employment contracts and bureaucratic procedures). But, in a version of a looping effect described by Douglas (1986), categorical models are themselves influenced by ways in which they are experienced and imagined in resource project localities.

\section{Categorical Dissonance}

Building on Le Meur and Filer's take on categories as complex spaces rather than discreet entities, this chapter explores what I term here as 'categorical dissonance' which contrasts expectations of perceived roles and responsibilities with actual enactments and effects of those roles. The concept pivots on cognitive dissonance theory, first proposed by Festinger in the late 1950s, which 'suggests that when individuals hold two or more cognitions that are contradictory, they will feel an unpleasant statedissonance-until they are able to resolve this state by altering their cognitions' (Hinojosa et al. 2016: 171). I use it here to investigate the role of the state in stakeholder engagement at the Frieda River Project in PNG: to explore ways in which the absence of the state was experienced in the project location, and describe how the company developing the project and members of local communities responded and altered their cognition and actions to redress the imbalance these absences introduced into the process of planning for a mine at Frieda.

Two interconnected types of categorical dissonance will be described here. The first is dissonance within categories, found in dynamic spaces between categorical prescriptions of stakeholder roles and responsibilities, and their enactment in project contexts. In her study of kinship, law and the unexpected, Marilyn Strathern theorised two kinds of relations. The first kind, she wrote, are categorical relations, connections acquired through a logic or power of articulation that acquires its own conceptual 
momentum' (2005: 7). The second are interpersonal relations taken as connections between persons, which develop over time 'inflected in a precise and particular history' (ibid.). Together, the two create 'a tool for social living' as 'it is through interacting with persons that diverse interactions and further connections become intellectually conceivable, while it is through creating concepts and categories that connections come to have a social life of their own' (ibid.: 8). This chapter uses Strathern's framework to contrast the state's categorical presence with its interpersonal absences at the Frieda River Project. It describes how members of one of the project's so-called impact communities experienced the categorical prescriptions of state legislation which they could neither understand nor leverage, and how they became disillusioned with enactments of the state and the lack of interpersonal relationships with government agents. Instead, they vested their hopes in the relationships formed with mining company personnel, in anticipation of using those relations to leverage positive outcomes and bring civic infrastructure and services to the Frieda River area.

The second type is dissonance between categories, which emerges where one or more stakeholder groups fail to meet the expectations of their role leading to absences in their respective functions. Where this affects functions deemed necessary for the shared project, and where such absence arises in a way that threatens it, another actor (or actors) with the capacity to do so, will likely be forced to fill the missing role to address the disharmony and ensure continuity of the process. Although such 'absences' can be found in all stakeholder groups, this chapter focuses specifically on the state's performance against its categorical role at the Frieda River Project. It describes how the company developing the project has attempted to mediate the failures of the government, or its profound absence, and found itself under pressure to take on service delivery functions in the project area.

To demonstrate the multiple dimensions of the experiences of the state on the ground, in a project location, the chapter triangulates findings of a village-based ethnography with material collected among on-site company personnel and data from interviews conducted with government representatives during their rare visits to the area. It follows stakeholders engaged in the process of planning for a mine at Frieda River in their use of categorical terminology, referring broadly to the government, the company, and 'local' or 'impact' communities as key stakeholder groups at the Frieda River Project. It shows how the Paiyamo community of 
Paupe, who live in the vicinity of the project, strived for a relationship with the state and strategically engaged the company to fill some of the voids created by the gap between expectations and reality of government involvement at the Frieda River Project. An important part of this process was the anticipation that if the mine begins operations, the government's interest and its active presence in these communities will follow. This chapter follows local use of the Tok Pisin term gavman, translated here as government, to describe the state, its institutions and people who enact it at any given point in time-expanding on the view of the state as a discrete polity made up of organising rules and principles and possessing the power to enforce those over particular peoples and territory, to include people who enact it and enforce its policies in the project location. It is based on ethnographic material collected during 12 months of fieldwork conducted in the Frieda area in 2011-12 and again in 2018.

\section{Emergence of the State}

The image of the Australian flag being lowered and the Papua New Guinean one being raised signalling the birth of an independent PNG is widely used in descriptions of the moment in which PNG became an independent nation state. The red, black and gold bird of paradise flag on a mast at sunrise on 16 September 1975 was heralded in the national media as a symbol of a new dawn, uniting the independent nation state around imagery filled with hope and anticipation of a bright future. The public rhetoric surrounding independence created an idea of a nation state akin to Benedict Anderson's (1983: 6) model of an 'imagined community'-a group of people, spread over a particular geographic area, who will likely never meet 'yet in the minds of each lives the image of their communion' (see also Main, Chapter 5, this volume). Accounts of the time leading up to the event speak of high levels of excitement, particularly and understandably in the capital district where official celebrations were taking place, attended by powerful political figures from across the country and abroad.

In the mid-1970s, the newly formed nationalist discourse pivoted on the powerful idea that independent PNG will also be a 'developed' PNG. Despite early national optimism, in the years following independence the newly established government struggled to fulfil its development aspirations. Even though the experience of colonialism was brief for 
a large proportion of the population, it left a lasting legacy of expectations and shaped the ways in which citizens of the newly independent nation conceptualised the state and the role of the gavman. Accounts of the emergence of the 'state' in PNG describe the state, seen as regulator and provider of infrastructure and services, as very much a colonial creation and describe how, particularly in the years between the Second World War and independence, the colonial administration played a key role in 'development' (May 2004). As it withdrew, the colonial administration left voids in the provision of services, and the maintenance and development of infrastructure. While the country's public service was functional, its capacity to deliver services and respond to the needs of the country's growing population was relatively limited (Gelu 2010) meaning that gradually, in the years following independence, in large parts of the country civic infrastructure wilted and access to government services diminished.

Like the experience of colonial administration before it, the experience of the state of PNG was unevenly shared across the nation following independence. To an extent this is still the case today, with people in many rural parts of the country expressing feelings of being forgotten by the government and excluded from national political representation and capital flows. In 1975 'many of the new state's claims to legitimacy were based on the promise that all Papua New Guineans could expect development to come their way' (Jorgensen 2007: 58). By the 1980s tensions arose between the goals of 'development for all', set out in the country's largely egalitarian Eight Point Plan (1975), and the realisation that development, out of its very nature, produces inequality (Rivers 1999; Stead 2016). The mining industry seemed to offer an ideal opportunity to bring revenues to the national economy and development into local areas (Gilberthorpe and Banks 2012). The government embraced the promise of mining-induced national development. By the end of the 1970s, PNG became a 'mining resource frontier' (Hyndman 2001). Over time, mining become a central feature of the country's growing economy, capitalising on what Ballard and Banks (2003) referred to as the 'mining exploration bonanza' of the 1980 s and early 1990s. By then, at least 10 large mineral prospects had been identified in PNG, and national leaders restated the promise that 'mining revenues will be the catalyst for an ambitious program of rural development and that capital works programs and government services will enable subsistence villagers to enjoy the benefits of the cash economy, hitherto largely confined to the urban minority' (Ashton, 1990). By the 
end of the twentieth century, 156 mining exploration licences had either already been awarded or were awaiting grants, and four major operations (Ok Tedi, Lihir, Misima and Porgera) and one medium-sized mine (Tolukuma) operated in PNG (Hirsch 2001).

The 1990s saw intensification of exploration activities in many parts of the country, including the copper and gold prospects in the Frieda River area. The companies' increasing presence on the ground and their interactions with members of host communities established exploration and mining companies as powerful social, economic and development agents across the nation. In light of the ongoing decline in the provision of government services, and increasing disillusionment with the government's capacity to maintain and expand civic infrastructure, local communities looked to mining and exploration companies to fulfil those roles-with the companies' ability to secure local consent for their operations, known in the industry as a 'social license to operate' (SLTO), ${ }^{2}$ increasingly influenced by their performance against those expectations. This anticipation was shared by many local and provincial governments that linked their own ability to cater to the needs of their communities to their success in attracting and retaining mining interests in their area. For some people, the enabling legislative climate created by the state in the hope of encouraging growth of the industry was the state's way of helping its citizens.

While people hoped that the companies would bring development to their areas in the form of infrastructure, services, and employment and business opportunities, in the decades following independence the government was very much hoping for the same. Unsurprisingly, over the years, companies tended to resist taking on what they saw as the role of the government. Nevertheless, faced with the necessity to secure support for their projects from the host communities, and confronted with the weak institutions of the state, many companies have found themselves with no choice but

2 Although it adapts technical and tangible language associated with licencing and permitting, in reality SLTO is 'an intangible construct associated with acceptance, approval, consent, demands, expectations and reputation' (Parsons et al. 2014: 84). The term has been criticised on the grounds of limiting, not expanding, critical debates about entanglements and regimes of responsibility and accountability between companies and society (Owen and Kemp 2014). Despite risks associated with the way in which the concept 'constructs its notion of approval, based on the absence of disapproval' (Owen 2016: 103), it has become a popular shorthand to describe ways in which companies deliver benefits to communities in exchange for the latter not interrupting their local operations. 
to either fill these gaps (see also Bainton and Macintyre, Chapter 4, this volume), or facilitate the government in fulfilling its role, and most often both-as the remainder of this chapter will show.

\section{The Frieda River Project}

As the global geographies of demand and supply in mineral resources shift (Bebbington et al. 2008), deposits that have been long considered either too dangerous or economically unviable are having their viability reassessed. Frieda River's copper and gold deposit falls into this category. It is what can be described as a 'complex ore body', where this complexity includes a range of geographical, geological and non-technical factors, such as political uncertainties and social and cultural complexities (Valenta et al. 2019). Frieda River is not a mine, but an advanced resource exploration project.

Even by Papua New Guinean standards, the Frieda River Project is geographically remote. Located near the border between East Sepik and Sandaun provinces, some $70 \mathrm{~km}$ south of the Sepik River, the site is not accessible by road from either of the provincial capitals, Vanimo or Wewak, but it can be reached by air, using a helicopter or a lightweight plane, or by water-following the Sepik from Pagwi in the East Sepik or from Green River in Sandaun. Despite its geographic isolation (see Figure 2.1), the area's rich copper and gold deposits mean that it is of great interest to the mining industry, and has been for a number of decades. Mineral prospects were first identified at Frieda during a regional mapping exercise in 1966. In 1969 a Prospecting Authority (today known as Exploration License 58) was granted to an Australian mining company, Mount Isa Mines Ltd, and its subsidiary, Carpentaria Exploration Company, allowing for exploration work at Frieda to begin. Exploration has been ongoing since, but noticeably intensified in 1996 when, in the middle of the global resource high, Highlands Gold Properties Pty Ltd completed the first full feasibility study for the Frieda River Project. The second feasibility study was completed in 2013 by Xstrata Frieda River, a subsidiary of Xstrata Copper, which at the time was the fourth largest copper producer in the world. Xstrata withdrew from the project a short time later. 


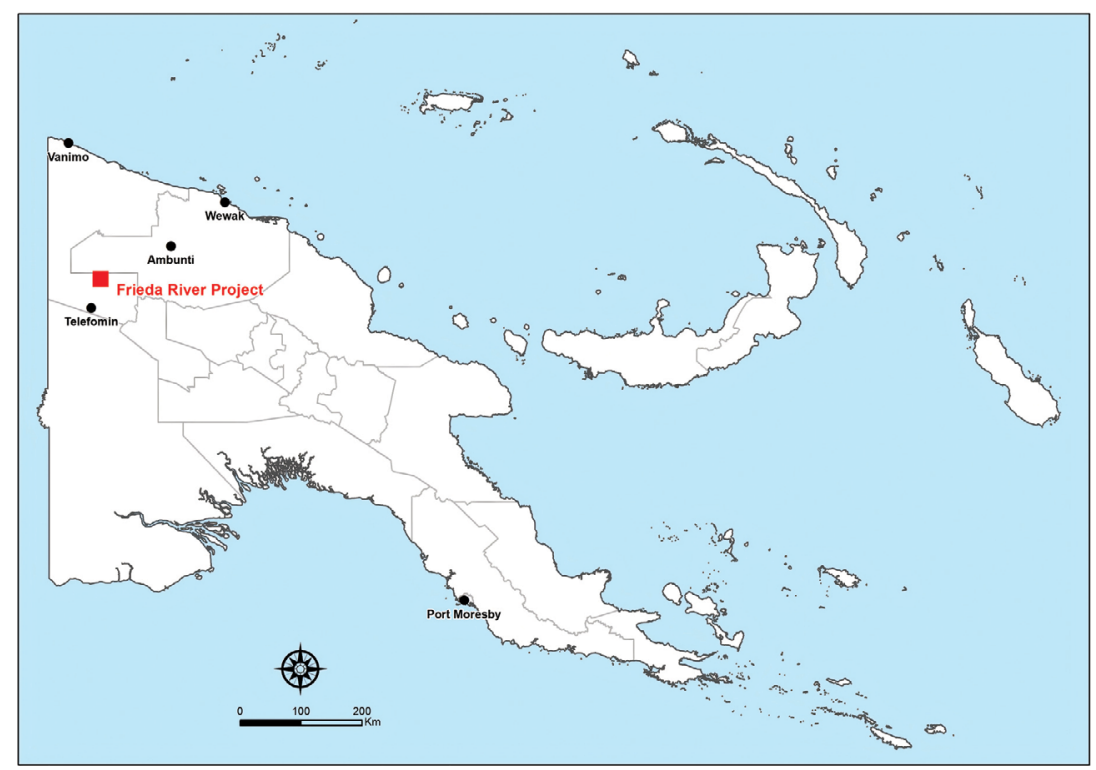

Figure 2.1 Location of the Frieda River Project

Source: Map created by Kamila Svobodova

The Frieda River Project is now co-owned by Brisbane-based PanAust (80 per cent $)^{3}$ and a Papua New Guinean incorporated company, Highlands Pacific Ltd (20 per cent). The current owners see Frieda River as 'a core component of a transformative nation-building opportunitywhich the company has dubbed the Sepik Development Project' that promises to 'deliver direct and indirect local employment, create business opportunities, attract foreign investment and boost trade and commerce' (PanAust 2018). Company materials publicly promoting the project claim that:

host communities, especially in rural areas, will benefit from access to improved transport, telecommunications, health, education and government services that will support a higher quality of life and greater social participation. More broadly, training and employment of Papua New Guineans will provide the skills and capacity to support the nation's future development and prosperity. (ibid.)

3 In 2015, soon after it acquired shares in the Frieda River Project, a Chinese companyGuangdong Rising Assets Management, acquired PanAust. It is now fully Chinese-owned, but continues to operate from Brisbane, and remains listed on the Australian Stock Exchange. The majority of the on-site personnel are either Papua New Guinean or Australian. 
The promotional materials do not specify who will deliver those benefits, only that they will be substantial.

Frieda River Joint Venture partners were, at the time of writing, in the process of making adjustments to their feasibility study with a view of submitting a Special Mining Lease (SML) application to the state government, as required by the Mining Act-the main instrument of mining industry governance in PNG. The licence is granted on the basis of the application and conditional to successful completion of a development forum-a process of tripartite consultations between government, company and community representatives developed by the government 'for addressing issues of community participation' and distribution of landowner benefits in resource extraction projects (IIED 2002: 211, see also Filer 2008). Granting of the SML opens the door for companies to proceed to the construction and operations phases of the mineral project life cycle.

Since the turn of the century, on-site exploration activities at Frieda were tailored towards servicing the demands of the consecutive feasibility studies, including but not limited to hydrological testing, drilling programs and technical scoping for the project's numerous designs. They also included environmental surveys, social mapping and landownership demarcation exercises, and community engagement activities. At the time of research, the company maintained a presence of operations and community affairs personnel on site. In 2011-12, the community affairs team consisted of three superintendents and seven to eight officers, who were all accommodated in one of the two semi-permanent residential camps-the Base Camp and the Airstrip Camp. In 2018 the team was smaller, comprising of two superintendents and six officers, working on a roster. On both occasions, the team was led by a manager based in the company's office in Brisbane. While the on-site teams interacted with representatives of provincial and district governments, particularly during their visits to the site, the relationship with the national government was largely handled by the company's Brisbane-based general manager for 'external affairs'. 


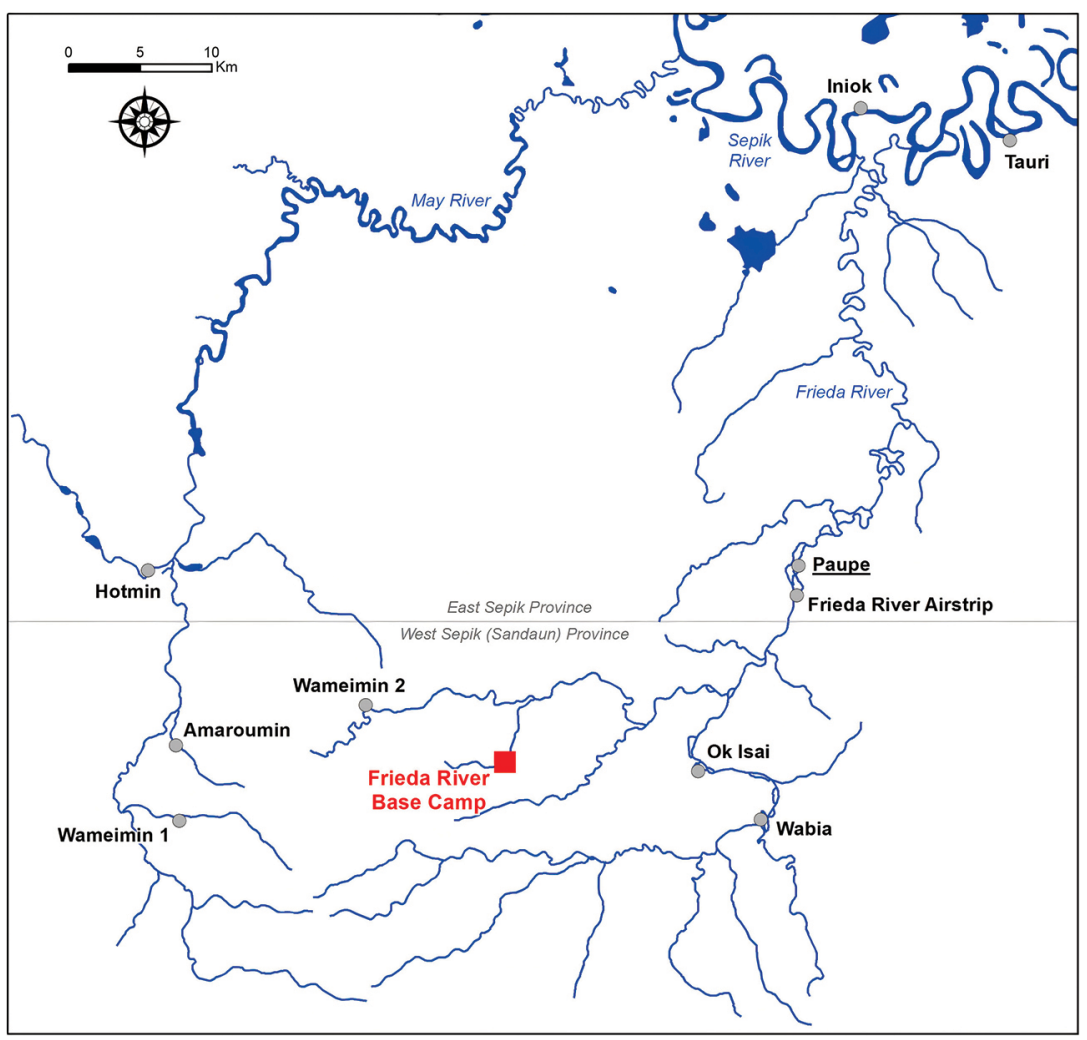

Figure 2.2 Frieda River Project area

Source: Map created by Kamila Svobodova

Following a landowner identification exercise for an area under Exploration License 58, requested by the government and completed by the company in 1995-96, seven communities were awarded a status of what are now known as 'impact communities' of the Frieda River Project: Telefolmin villages of Ok Isai and Wabia; Mianmin villages of Wameimin 1 and 2, Amaroumin, and Hotmin; and a Paiyamo village of Paupe, where I was based for most of the time I spent at Frieda (see Figure 2.2). Located in the East Sepik Province, a short boat ride away from the Sandaun provincial border, and a few minutes' walk away from the Airstrip Camp, Paupe is a truly beautiful place nestled in the rainforest. At first glance, there is little to signify Paupe's status as an impact community to a large, advanced resource exploration project, based upon the visible signs of development that we have come to expect in 'mining impact communities'. In the absence of actual mining, Paupe is really an 'exploration impact community'. Most of its 
members continue to live in temporary houses made of bush materials, and subsistence agriculture remains the main economic activity in the village. Saying that, during the time I have spent in the area, there have been some noticeable changes in community infrastructure and services. In that time, and with the company's assistance, Paupe gained new school buildings and a community clinic, complete with staff housing. A gravel service road now runs through the community linking the Airstrip Camp with Paupe, and further with a water port on the banks of the Sepik River. The service road was built by the company to enable transport of cargo between supply barges moored on the Sepik and the company camp. In 2018 my hosts told me, with more than a note of excitement in their voices, that when the road was being built a PMV (public motor vehicle, a popular bus substitute in PNG) travelled through Paupe, bringing workers to site in the morning, and returning them to the Airstrip Camp in the afternoon. Although the PMV runs ceased once the construction was completed, the image of a bus passing through the community stayed with the Paiyamo, evoking imagery of the kinds of services they will have access to once the project proceeds from exploration and permitting to the construction and operations phases of its life cycle.

\section{The Absent Presence of the State}

The Paiyamo's first encounters with state administration occurred relatively late in the country's colonial history, with the first government patrol officer (or 'kiap') reaching the area in 1962. The kiap brought together Paiyamo speakers dispersed around the region, and established the foundations of the current village of Paupe. In local narratives, this marks a moment of transition from past-focused time of the ancestors, to a future-driven time of 'white men' and 'development'. The Paiyamo rarely speak about their first experiences of the government. But when probed they talk about establishment of the village, advent of local administrative roles like luluais (village heads or chiefs) and tultuls (their assistants), introduction of village books, and first encounters with organised law and order structures which saw a group of local men arrested and taken to jail in Ambunti, the district headquarters, in the late 1960s. From its early days, the relationship between the Paiyamo and the gavman was weak, and limited to sporadic and brief encounters with colonial patrols. Even now, the Paiyamo feel very little obligation towards the state and ascribe much greater significance to another arrival—which followed a few years 
after the first kiap moored his boat on the banks of the river-the mining company. Over time, members of local communities came to see the mining industry as a 'modern road to cargo' (see also Bainton 2010) and began to conceptualise the future mine as a portal through which they will gain access to 'development'.

For all intents and purposes, the way the Paiyamo see it, they do not have a relationship with the government independently of the Frieda River Project, and they look to the company for what would traditionally be seen as the role(s) and responsibilities of the state. "We must support the company and work with them. It is the company that will bring services to us. It will not be the government who will come and give medications to our children. If the company was not there, the government would not remember about us', I often heard them say. The self-description as 'people forgotten by the government' featured strongly in such statements, as the Paiyamo turned to the company for goods and services, which they came to associate with the promise of development and modernity they read from the imagery of the anticipated copper and gold mine in their area.

Despite their brief and limited encounters with the colonial administration, like many people all over the country, they too spoke of a decline in government presence in the years since independence. 'These are no longer the times when Australians were looking after us and when there was enough of everything for everyone. We should be happy we have the company here because the government has completely forgotten about us', I was told by a community leader in Paupe. In the few encounters I witnessed between Paiyamo people and government representatives, the latter actively encouraged the communities' dependency on the company for both civic infrastructure and basic services, laying bare the government's own expectations of the company to deliver development to what it saw as some of the most geographically remote and hard-toaccess parts of the country. On one occasion in 2012, during a brief visit to Paupe, I heard a member of the provincial administration say to the community:

Before, you all lived in the bush and you had nothing. The government is too far away, it will not help you. If it was not for the company you would still be in the bush with no development, nothing. If you don't support the company, you will go back there. 
This is not to say that the government was completely absent from the project and the area. National legislation meant that, in categorical terms, the state's presence was very much felt at Frieda. It was demonstrated through prescriptions of government forms, laws, procedures and-last but not least-the sovereign power held by the government to grant the SML for the project. The company would often bring the state into conversations by invoking government process and legislation to explain its own decisions and actions, and to settle disputes on issues such as compensation rates. From the perspective of local communities, the government processes were slow, and were often blamed for holding back the mine. This meant that there was also a temporal dimension to the categorical presence of the government at the Frieda River Project (cf. Dalsgaard 2013).

In many ways, the categorical presence of the state at Frieda, where subsistence and artisanal mining activities kept people largely outside the formal economy and taxation system, and where most law and order issues were settled using prescriptions of customary rather than common law, was felt more strongly in the context of the project than in any other area of people's lives-the project serving as a tool for local anchoring of the state at Frieda. But this categorical presence of the state was not equal to a relationship - which the Paiyamo were very quick to remark upon when I asked. It lacked the interpersonal component and access to government representatives with whom consequential relations could be leveraged and built. In that regard, the interpersonal absences, lack of direct interactions with government officials, and poor delivery of government services in the area contributed to the feeling that the state was absent from Frieda. ${ }^{4}$ These feelings were exacerbated by the community members' very limited understanding of government processes and systems - $\mathrm{a}$ form of institutional uncertainty about the rules of the new game (see also Minnegal and Dwyer 2017). On more than one occasion I heard people ask 'How can we participate fully if we do not understand?' This led to high levels of frustration among the Paiyamo who, faced with

4 Since independence, Paupe has had a local government councillor. Formally the holder of this elected position served as an intermediary between the community and the state, together with the village court magistrate. Generally, the Paiyamo respected their local councillor and his role in resolving community matters. However, they had little confidence in the subsequent post-holders' ability to leverage relations with 'the state'. Limited interaction and communication between the councillor and higher levels of government, and the company's emphasis on district, provincial and state representatives meant that while respected within the community, the councillor was not considered a fully-fledged 'government representative' in Paupe. 
state regulations and bureaucratic prescriptions that were inflexible and non-negotiable, felt they could not really get to know the government. Further, as their local epistemology treats knowledge as a relational endeavour, they took the government's lack of interest in entering into interpersonal relationships with members of the community as a sign of the state's unwillingness or lack of interest in getting to know them.

Local ideas of personhood play an important role in the processes described here. The Paiyamo judge knowledge and relations against the transformative effects these have on the world. For them, personal relations award meaning and significance to past and current events, and create opportunities for the future. Over time, my hosts in Paupe came to see the (future) Frieda River Mine as an effect of knowledge and relations, which they actively navigated hoping to reveal the long-awaited mine in their area (Skrzypek 2020). Which is why the almost exclusively categorical presence of the state, which they did not know and felt did not want to know them, and with which no two-way relationship could be developed, was so frustrating. In the absence of interpersonal relations with the government, members of Paupe community did not identify with it in a way in which they came to identify with the company developing the project, and did not form relations with government representatives in the way they entered into complex relations with company employees. There was a strong categorical relationship between the Paiyamo and the company, grounded in the national Constitution and prescriptions of legally recognised customary land ownership. In this relationship, the company (the developer) must secure and maintain access to land owned by the Paiyamo (the landowners) in order to develop infrastructure essential for the project's activities and future operations (Bainton and Banks 2018). However, to my hosts in Paupe, it was the interpersonal relations they entered into with the company's on-site personnel that made the categorical relations meaningful and gave them effect, with the ultimate goal of leveraging those relations to precipitate a mine at Frieda. On my most recent visit to the area I was told by a company representative that now, even when the government representatives visit the villages, they are given less priority than the company personnel, the latter seen as more capable to impact change and address their desires and concerns. In his view, 'people no longer believe the gavman will help them'. 


\section{Community Leaders' Forum}

The problematic relationship, or the lack of association, between government representatives and community members had an effect on the company and the way in which it approached the task of 'stakeholder engagement' at the project. Company representatives frequently raised concerns about the government's limited capacity to proactively engage with the project, and the country's political instability, which, in their view, weakened the state's position as the regulator of the industry. 'At the national level, elections are coming up next year and anything can happen', I was told in 2011. 'Personnel changes may mean setbacks, interests may change. The bureaucracy is slow. Laws can change all around the country. But all companies want security. They invest the money, they want to see it back'. Interestingly, this concern with the country's political instability was shared by many government representatives, including those based at the Mineral Resources Authority (MRA)—a government agency which acts on behalf of the national government to enforce rules and regulations at exploration and mining projects, who expressed frustration with the effect political processes had on their own ability to fulfil their administrative roles and responsibilities in the context of the Frieda River Project.

Rather unsurprisingly, company employees felt uncomfortable with refracted responsibilities and the pressure they have found themselves under to fulfil what they saw as the role of the state. 'The government doesn't play its role. It thinks that since we are here we can provide all', a community affairs officer (CA) told me, following a community meeting in one of the impact villages. 'But we cannot be seen as the provider of government services in the area-this is just not right', he added, signalling that the absence of state function was not only a practical but also a moral issue. In an attempt to manage the absence of the government representatives at Frieda, and to fill the void in interpersonal relations between the government and local communities, the company management revived an old and for some time abandoned model of a 'community leaders forum' (CLF) - a common practice in the 1990s in the Project Coordination Branch of what was then the Department of Minerals and Energy. The revived forum was designed specifically to, in the words of one CA officer, 'connect landowners and the government 
representatives with the company present'. 5 The quarterly meetings brought government representatives, company personnel and community leaders together in the company's Base Camp to disseminate and discuss project-related information and, as it was described to me by one of the participants, 'to agree on common issues and allow everyone to move forward'. The meetings were intended as mechanisms for transparency, disseminating information at the same time to the different stakeholder groups, and ensuring accountability in decision making and acting on items agreed upon during the meetings. For many community leaders the forum did indeed offer a rare chance to interact with government representatives, although the forum did not address the bigger issue of the absence of state functions.

Generally, the list of government invitees included district representatives from Ambunti-Dreikikir and Telefomin, and an MRA representative. Depending on specific agenda items, representatives of relevant provincial government divisions would sometimes also be asked to attend. The costs and logistics of their attendance at CLF were covered by the company, who flew them into the area on either the company's fixed-wing charter or a chopper, and provided them with meals and accommodation in the Base Camp. This was a common arrangement for government representatives visiting the site. Often, on top of transport and accommodation, the representatives expected and received a daily stipend, to provide an additional incentive for travel to site. During the CLF, government representatives were encouraged to provide ward reports, speak about district priorities and provide updates on broadly conceived government issues. The invited representatives did not always come (on occasions leading the to the CLF being postponed or cancelled) and when they did, the level of their active participation in the meetings varied. Despite this, the company as well as community members spoke highly of the meetings and considered them to be the single most important stakeholder engagement mechanism at the project. A number of people I talked to in 2018 went a step further and described CLF as currently 'the main political body' for the Frieda River Project.

5 The company also meets with the two provincial governments and the MRA at the Joint Provincial Consultative Committee (JPCC) meetings. Held quarterly, usually shortly after the CLF, the JPCC meetings have been described to me as the 'main vehicles for formal interaction between the company and government stakeholders'. JPCC meetings are held away from Frieda and do not include community participation. 
While stakeholders on all sides told me that the forum created a valuable platform for discussion, agreeing on action items and allocating responsibilities for their delivery, community members felt that of the three broad stakeholder groups they had the least influence over forum proceedings. To quote one community leader and a regular CLF attendee:

we develop agendas. The company asks us to. But the agenda does not have power-our points get missed out, rejected. Why? Because this is our thinking. But it is good to bring everyone in a meeting. We come from different places we need to get together.

Echoing this sentiment, another community representative told me:

the CLF discussion is generally good. But sometimes we just sit and listen to what the company has to say. This has been changing as we give feedback, but there is room for improvement. For example, the company and the government- they need to change how they listen to us.

When probed about the last part of his statement, that particular person explained to me that issues brought to the table by the company take priority over issues presented by community, the latter often falling off the table altogether. This is reflective of a conflict of interpretation about the nature of this type of forum among the different participating groups and individuals. While community representatives tend to see them as opportunities for discussion, expressing discontent and resolving conflicts, companies more often see this as the opportunity to 'share information' and 'conduct awareness', and such processes tend to entail a much more one-sided flow of information.

There was also the issue of efficacy of agreements made during the CLFs. 'Sometimes, decisions are made at the CLF regarding certain projects, but nothing happens-no power, talk only', I heard in Paupe. Company representatives I spoke to about this told me that the meetings were established to move the project along a particular trajectory, set out by the requirements of government regulation and the company's own business processes and procedures. Where the CA officers reject agenda items, it was because they felt that they were either not appropriate for the forum, or wrongly timed - with the most time-sensitive and pressing issues needing to take precedence. While they acknowledged the great importance of having good relationships with the impact communities and their leaders, the CAs were open about the fact that the directives they received clearly prioritised moving the project towards an SML 
application. Ultimately, the forum was aimed at servicing the needs of the project, guided by the business rationality of the company. During my conversations with the CA officers, they spoke at length about how important it was that the government plays its role in the CLF and in the process of planning for a mine at Frieda, and how careful they had to be not to become a de facto government in the area. They also talked about the difficult task of trying to secure government's active involvement and engagement with the local communities, especially in the context of poor accountability and evasion of responsibility for their well-being (cf. Golub and Rhee 2013). Community members as well as company staff described numerous instances of government representatives making a promise and committing to a task or a project, which was never delivered.

For the CA officers it was important that the government representatives made promises directly to community leaders. This way, if the promises were not kept, the government, not the company (or the CA officers, for that matter) were held accountable for the failures-a coping strategy in a difficult work context. In a mirror process, it was not uncommon for government representatives to exercise a 'strategic absence' and avoid the meetings in order to avoid accountability, especially if they felt they lacked the capacity or were, for any other reason, unable to perform tasks and duties required of them. Reflecting on the impact of the CLF on the relationship between communities and the government, one CA officer told me: 'for people this is the only time they see the government. They out their complaints, demands and expectations. But do not actually expect the government to fulfil them'. 'No funding is their favourite excuse', I heard some time later in Paupe. But by far the most common reaction to my questions about promises made by the government representatives during the CLF and the state's involvement in delivery of services was a shrug of shoulders and the word maski (Tok Pisin for never mind, forget about it) uttered under the breath-signalling a certain resignation to the absence of the state.

\section{Refracted Responsibilities}

Aside from trying to facilitate a relationship between the government and local communities, the company actively worked on establishing its own relationship with government agencies and representatives. It resisted taking on service delivery responsibilities, and what it saw as the role 
of a 'quasi-government', but the CA officers felt that they did not have much choice if they wanted to maintain good relations with the impact communities, and to secure and maintain their support for the project. Over the years, the company made a concerted effort to collaborate with the government on facilitating access to basic services in the impact communities. For example, PanAust assisted the Telefolmin District Health division with delivery of quarterly health patrols in communities. This was one of few success stories. On many other occasions, company collaboration with government agencies encountered significant problems, like when the CA officers worked with communities to finance and erect a community clinic in Paupe. A government community health worker was brought in on a company charter plane to run and manage the facility. Although he was on the government payroll, he often did not receive payment for his work. He continued to fulfil his duties but was growing increasingly hesitant to do so. This was not the only instance where the government did not keep its side of the deal. As one CA officer explained to me 'school funding faced [a] similar challenge. And then service providers - the health worker, the teachers - turn to the company for help' ${ }^{6}$

While the high-level conversations between the company management and the national government happened away from Frieda, as the face of the company, time and time again the CA officers found themselves put on the spot during on-site meetings and gatherings. They spent a lot of their time managing community expectations, drawing lines in the sand to delineate their role from that of the government and encouraging communities to demand that the government provides them with basic services and fulfil its obligations to communities. 'The government thinks that we can solve all its problems'; 'The government is always two steps behind, not keeping up the pace'; 'The government relies too heavily on the company to provide development assistance. It is not taking initiative'; 'The government never played its role properly. As a result, the communities too are not being proactive with alternatives. They are just waiting for the company and the mine'. These are just some of the CA voices I heard which expressed frustration with the lack of active state involvement in services provision at Frieda.

6 It is not uncommon in PNG for schoolteachers and health workers not to get paid, especially in remote areas. 
Many company and government members I spoke to about the government's dependency on the company to fulfil some of its roles and responsibilities referred to the lack of government capacity to provide infrastructure and services to communities in the Frieda area, rather than the government's bad intentions or lack of willingness to do so. Some of my company interlocutors linked this to the weakness of the national government and saw this incapacity being passed down through all levels of state governance:

The governments know that it is their job, but they lack the resources, the manpower. They always thank us. They are very appreciative. They know that we are doing what they should be doing. But they lack the capacity and resources and as a result the company finds that it must provide services it really shouldn't have to.

Others were less sympathetic, of the opinion that the government purposefully took a step back and let the company fill the gap in providing services and development assistance to the local communities: 'The [company] feels compelled-it has no choice.' Sitting down for an interview with another, cup of tea in hand, I recorded him express a frustration echoed in many of the interviews I conducted with the company's on-site personnel: 'Government participation at early stages is lacking. CAs are caught in between. They cannot speak for the government. They should not have to.' Trapped in the state's strategic absence, CA officers have become reluctant policy brokers.

A number of district and provincial government representatives admitted that they depended on the company's assistance to bring development not only to the impact communities, but also to the two affected provinces. 'We are very remote here, we don't have development. With the mine, the company will bring the money for development', one of them told me. 'We understand the problems associated with mining projects and the impact it will have on the [Sepik] River. But if we don't get major development in the province, where do we get the money to help people?', I heard another official ask on a different occasion. Representatives of the national government shared this anticipation and also hoped to precipitate development of a mine at Frieda. As one MRA officer explained to me: 
The national government has one hope-for the project to develop as a mine. We are asking, preaching, hoping-when will it happen? When will the company submit the SML application? We are waiting happy to grant the lease. We are waiting for the economic impact and development. ${ }^{7}$

\section{Mind the Gap(s)}

Despite being host to numerous mining projects, and notwithstanding the industry's dominant presence in the national economy, PNG offers a challenging operating environment for mining companies. Upon arrival, companies find themselves caught up between what Emma Gilberthorpe and Glenn Banks (2012: 188) identified as the 'weak state' and the 'powerful local' and become 'entangled in a range of pre-existing local, regional and national political plays' over which they have little control. The weak state is incapable of regulating not just the corporation involved (see Wesley-Smith 1990; Toft 1997; and Walton 2015), but also the landowning communities with which companies find themselves entangled. As a result, I was told at the PNG Chamber of Mines and Petroleum - the peak representative body for the extractive industriescompanies in PNG find themselves 'operating against a backdrop of bad governance and ever growing community expectations'. In academic as well as public discourse, the country is often described in terms of a failed state, affected by the so-called resource curse (Ballard and Banks 2003), which has been linked to factors such as government's incapacity to distribute benefits to the people (Jackson 1991, and Main, Chapter 5 , this volume); underperformance of state institutions (Genasci and Pray 2008); disconnect between national-level decision makers and society (Collier 2008); and the government's preoccupation with distant opportunities over locally defined social and economic goals (Connell and Howitt 1991). These macro-level assessments (see Gilberthorpe and Papyrakis 2015) judge the government's performance against the

\footnotetext{
7 This is not to suggest that there were no people in both provinces who opposed the Frieda River Project. While their views were reflected by the provincial representatives, their arguments were generally overshadowed by the desperate need for basic services and infrastructure in the two provinces, emphasised by the government's self-admitted reliance on the industry to deliver 'development' to the region. The level of opposition increased in 2018 when the developer announced major changes in the design of the project, and further in 2019 following the company's publication of an Environmental Impact Statement for the Frieda River Project (see Skrzypek 2020).
} 
expectation of state function, and the promise it made at independence to strategically engage the mining industry with the aim of securing positive development outcomes for the country and its people.

At a micro-level, my hosts in Paupe tended to describe their relationship with the government in terms of absences and deficiencies. The fact that Frieda River is not an operating mine but an advanced mineral exploration project means that the area has not yet experienced the entrenched negative localised impacts present at the many mines operating across the country. ${ }^{8}$ However, the way in which the government is experienced by community and company stakeholders in the project location already points to performance and capacity gaps commonly associated with the resource curse, judged against categorical prescriptions of the role of the state as a regulator for the industry, and provider of services, infrastructure and effective governance for its people. The Paiyamo talked about the government that has forgotten them, that never came to see them. They also spoke of the government's failure to deliver and maintain basic services and the ease with which it made promises, which, the Paiyamo learned over time, it almost never kept. Desire for services and infrastructure and high expectations of 'development' which formed at Frieda in the decades since independence meant that there were numerous gaps between what they understood the role of the government to be, and the government's performance against this role. The way in which the categorical presence of the government in the process of planning for a mine at Frieda contrasted with its interpersonal absence further exacerbated the situation, creating in Paupe a sense of the government's presence most strongly experienced through its absence. The Paiyamo saw the mining company as a way of filling this gap, at least insofar as it demonstrated through securing access to what they came to see as indicators of development-services, infrastructure, learning and earning opportunities. They considered their ability to form interpersonal relations with company representatives as a crucially important part of this process, with the ultimate goal of leveraging those relations to precipitate a mine at Frieda. Despite their difficult experiences of gavman to date they hoped that, once the mine starts operating, the gavman will step up and become more actively involved in 'looking after its people and communities'. In spite of decades of engagement and exploration, they have not yet succeeded in this task.

8 See, for example, Golub (2014) on Porgera; Bainton (2010) on Lihir; and Kirsch (2014) on Ok Tedi. 


\section{Conclusions}

Stakeholder categories are based on a series of assumptions and expectations about their nature and effect. Governance mechanisms commonly used to guide stakeholder engagement in resource extraction projects further reinforce such categorical prescriptions. On face value at least, categorical models of stakeholder relations are grounded in a belief that, in entering into a relationship, the stakeholders accept roles assigned to them by the model, and further that they have the capacity required to enact them and achieve the desired effect. For example, the popular triad stakeholder model reflects a belief that, as a regulator and a main service provider, the state can and will regulate the industry, and provide services for its people. Furthermore, engrained in categorical models is the implication that stakeholders representing different categories have the means of holding the others accountable for their performance against their designated roles and responsibilities. To that end, such models tend to reflect an erroneous assumption that power inequalities can be treated as externalities, painting a deceptively apolitical picture of highly politicised relations and dependencies.

Conceptually, the models stipulate that if all stakeholders enact their categorical roles and meet conditions of their categorical relations, the process will succeed. In the ethnographic example presented here, this success is anticipated to take form of the Frieda River Mine. However, like any attempt at categorisation and standardisation, such models 'assume a set of conditions that do not exist in most of the world' (Newell 2005: 556). Once the categorical stakeholder model is enacted in a real-life scenario of a resource exploration (or extraction) project, categories are exposed to power inequalities, different world-views, political relations, personal interpretations and a range of other socioeconomic forces, which the conceptual models push aside or hide. What emerges is a form of dissonance which questions prescriptive categories on the basis of enactment and effect of those; and forces some or all of the stakeholders to revise their understandings of their roles and responsibilities at the project.

Cognitive dissonance theory helps us explore how people deal with uncertainty, making it useful for thinking through impacts and implications of resource exploration projects characterised by prolepsis, anticipation and desires to effect and affect the future (see Minnegal and Dwyer 2017; and Skrzypek 2020). In cognitive dissonance theory, when there is an 
inconsistency between attitudes or behaviours, something must change to eradicate the disharmony (Festinger 1957). In a similar way, categorical dissonance stipulates that where there emerges inconsistency between expectations of roles and their enactments, something must change to alleviate the tension and eliminate the risk of project failure. At the Frieda River Project, members of local communities saw the potential future mine as a pathway to development, a 'modern road to cargo'. They associated the mine with industrial development, but even more so with civic infrastructure and widespread access to education, services and earning opportunities. Their expectations were high, having grown over time, fuelled by generous promises made by early exploration companies who sought to secure access to their land for exploration and, when the time comes, mining purposes. Government representatives visiting the area not only encouraged but actively partook in this imagery of mining as a pathway to development and a road to wealth and cargo. As described early on in this chapter, the country has a long history of deficiencies in service delivery and high levels of dependency on the extractive industries for both national economic growth and localised forms of development. In anticipation of a large-scale mine, in the Frieda River area, as in many other resource-rich parts of the country, the government has largely abdicated its service and infrastructure delivery responsibilities, refracting them instead onto resource extraction companies.

The ethnographic material presented here described dissonance created by expectations of the state's function and the government's performance against that role; the gap formed by its categorical presence and interpersonal absence from the project area; and the company's response to local communities' and the government's expectations of service delivery assistance. The company resisted becoming a 'quasi-government' and felt that was not part of its role as the project's key investor and operator. However, in order to maintain local communities' and the government's support, its representatives felt that they had no choice but to alter what they saw as the boundaries of the company's role and, consequently, behaviour at the Frieda River Project. The company took on some of the state's service delivery responsibilities, and facilitated the relationship between the government and communities, thus mediating the failure and absence of the government from the local nexus of relations, and from the service delivery landscape. It did not do so because it wanted to- the company's ideas about community development and engagement programs saw their function as 'in extension' rather than 'in place' of 
government provision of basic services. The company took on elements of the role of the state because this allowed it to advance its interests and fulfil its primary role—as a commercial business and project developer.

Such corrective behaviour associated with categorical dissonance brings to light critical limitations of oversimplified stakeholder models, which assume conditions that do not exist in the lived experiences of stakeholders in resource contexts. In this case, the company's behaviour responded to state absences and pointed to gaps between prescriptions and expectations of the state role at the project, and the government's performance against those. However, rather than exposing the shortcomings of the model, and holding the government accountable for its failure to fulfil its obligations, the company provided it with a self-correction mechanism. Its actions meant that the government's demonstrated absence and underperformance against its prescribed stakeholder role was mediated, as the developer filled the very gaps that could have threatened the future of the project. As a result, while the company and the Paiyamo faced ongoing tension and conflict over the allocation of responsibilities, viewed from a distance, the demands of the categorical model were met, and the project could continue moving forward towards the desired effect-the Frieda River Mine.

\section{Acknowledgements}

The work presented here was made possible by funding from the European and Social Research Council (UK) —award number ES/1904107/1, and the European Union's Horizon 2020 research and innovation program under the Marie Sklodowska-Curie grant agreement No. 753272.

\section{References}

Anderson, B., 1983. Imagined Communities: Reflections on the Origin and Spread of Nationalism. London: Verso Books.

Ashton, C., 1990. 'Papua New Guinea: A Broken-Backed State.' Quadrant 34(7/8): 25-30.

Bainton, N.A., 2010. The Libir Destiny: Cultural Responses to Mining in Melanesia. Canberra: ANU E Press (Asia-Pacific Environment Monograph 5). doi.org/ $10.22459 / \mathrm{ld} .10 .2010$ 
Bainton, N. and G. Banks, 2018. 'Land and Access: A Framework for Analysing Mining, Migration and Development in Melanesia.' Sustainable Development 26: 450-460. doi.org/10.1002/sd.1890

Ballard, C. and G. Banks, 2003. 'Resource Wars: The Anthropology of Mining.' Annual Review of Anthropology 32: 287-313. doi.org/10.1146/annurev. anthro.32.061002.093116

Banks, G.A. and C. Ballard, (eds), 1997. The Ok Tedi Settlement: Issues, Outcomes and Implications. Canberra: The Australian National University, National Centre for Development Studies (Pacific Policy Paper 27).

Bebbington, A., L. Hinojosa, D.H. Bebbington, M.L. Burneo and X. Warnaars, 2008. 'Contention and Ambiguity: Mining and the Possibilities of Development.' Development and Change 39(6): 887-914. doi.org/10.1111/ j.1467-7660.2008.00517.x

Collier, P., 2008. 'Laws and Codes for the Resource Curse.' Yale Human Rights and Development Law Journal 11: 9-28.

Connell, J. and R. Howitt, 1991. 'Mining, Dispossession, and Development.' In J. Connell and R. Howitt (eds), Mining and Indigenous Peoples in Australasia. Sydney: Sydney University Press.

Dalsgaard, S., 2013. 'The Time of the State and the Temporality of the Gavman in Manus Province, Papua New Guinea.' Social Analysis 57: 34-49. doi.org/ $10.3167 /$ sa.2013.570103

Douglas, M., 1986. How Institutions Think. New York: Syracuse University Press.

Festinger, L., 1957. A Theory of Cognitive Dissonance. Stanford (CA): Stanford University Press.

Filer, C., 2008. 'Development Forum in Papua New Guinea: Upsides and Downsides.' Journal of Energy \& Natural Resources Law 26: 120-150. doi.org/ 10.1080/02646811.2008.11435180

Filer, C. and P.Y. Le Meur, 2017. 'Large-Scale Mines and Local-Level Politics.' In C. Filer and P.Y. Le Meur (eds), Large-Scale Mines and Local-Level Politics: Between New Caledonia and Papua New Guinea. Canberra: ANU Press (AsiaPacific Environment Monograph 12). doi.org/10.22459/LMLP.10.2017.01

Freeman, R.E., 2010 [1984]. Strategic Management: A Stakeholder Approach. Cambridge: Cambridge University Press. 
Gelu, A., 2010. 'Politics and Governance.' In T. Webster and L. Duncan (eds), Papua New Guinea's Development Performance 1975-2008. Port Moresby: National Research Institute (Monograph 41).

Genasci, M. and S. Pray, 2008. 'Extracting Accountability: The Implications of the Resource Curse for CSR Theory and Practice.' Yale Human Rights and Development Law Journal 11:37-58.

Gilberthorpe, E. and G. Banks, 2012. 'Development on Whose Terms? CSR Discourse and Social Realities in Papua New Guinea’s Extractive Industries Sector.' Resources Policy 37: 185-193. doi.org/10.1016/j.resourpol.2011.09.005

Gilberthorpe, E. and E. Papyrakis, 2015. 'The Extractive Industries and Development: The Resource Curse at the Micro, Meso and Macro Levels.' Extractive Industries and Society2:381-390. doi.org/10.1016/j.exis.2015.02.008

Golub, A., 2014. Leviathans at the Gold Mine: Creating Indigenous and Corporate Actors in Papua New Guinea. Durham (NC): Duke University Press.

Golub, A. and M. Rhee, 2013. 'Traction: The Role of Executives in Localising Global Mining and Petroleum Industries in Papua New Guinea.' Paideuma 59: 215-236.

Hinojosa, A.S., W.L. Gardner, H.J. Walker, C. Cogliser and D. Gullifor, 2016. 'A Review of Cognitive Dissonance Theory in Management Research: Opportunities for Further Development.' Journal of Management 43: 170-199. doi.org/10.1177/0149206316668236

Hirsch, E., 2001. 'New Boundaries of Influence in Highland Papua: "Culture", Mining and Ritual Conversions.' Oceania 71: 298-312. doi.org/10.1002/ j.1834-4461.2001.tb02755.x

Hyndman, D., 2001. 'Academic Responsibilities and Representation of the Ok Tedi Crisis in Postcolonial Papua New Guinea.' Contemporary Pacific 13: 33-54. doi.org/10.1353/cp.2001.0014

IIED (International Institute for Environment and Development), 2002. Breaking New Ground: Mining, Minerals and Sustainable Development. London: IIED, Mining Minerals and Sustainable Development Project.

Imbun, B.Y., 2007. 'Cannot Manage without the "Significant Other": Mining, Corporate Social Responsibility and Local Communities in Papua New Guinea.' Journal of Business Ethics 73: 177-192. doi.org/10.1007/s10551006-9189-z 
Jackson, R., 1991. 'Not Without Influence-Villages, Mining Companies and Government in PNG.' In J. Connell and R. Howitt (eds), Mining and Indigenous Peoples in Australasia. Sydney: Sydney University Press.

Jorgensen, D., 2007. 'Clan-Finding, Clan-Making and the Politics of Identity in a Papua New Guinea Mining Project.' In J.F. Weiner and K. Glaskin (eds), Customary Land Tenure and Registration in Australia and Papua New Guinea: Anthropological Perspectives. Canberra: ANU E Press (Asia-Pacific Environment Monograph 3). doi.org/10.22459/cltrapng.06.2007.04

Kirsch, S., 2014. Mining Capitalism: The Relationship Between Corporations and Their Critics. Oakland: University of California Press.

May, R.J., 2004. State and Society in Papua New Guinea: The First Twenty-Five Years. Canberra: ANU E Press. doi.org/10.22459/SSPNG.05.2004

May, R.J and M. Spriggs (eds), 1990. The Bougainville Crisis. Bathurst (NSW): Crawford House Press.

Minnegal, M. and P.D. Dwyer, 2017. Navigating the Future: An Ethnography of Change in Papua New Guinea. Canberra: ANU Press (Asia-Pacific Environment Monograph 11). doi.org/10.22459/NTF.06.2017

Newell, P., 2005. 'Citizenship, Accountability and Community: The Limits of the CSR Agenda.' International Affairs 81(3): 541-557. doi.org/10.1111/j.14682346.2005.00468.x

Owen, J.R., 2016. 'Social License and the Fear of Mineras Interruptus.' Geoforum 77: 102-105. doi.org/10.1016/j.geoforum.2016.10.014

Owen, J.R. and D. Kemp, 2014. 'Mining and Community Relations: Mapping the Internal Dimensions of Practice.' Extractive Industries and Society 1: 12-19. doi.org/10.1016/j.exis.2013.12.004

PanAust, 2018. 'A Nation-Building Development Pathway for the Frieda River Project.' Press release, 11 December. Viewed 16 September 2020 at: panaust. com.au/sites/default/files/201812_A\%20nation-building\%20development \%20pathway\%20for\%20the\%20Frieda\%20River\%20Project_0.pdf

Parsons, R., J. Lacey and K. Moffat, 2014. 'Maintaining Legitimacy of a Contested Practice: How the Minerals Industry Understands Social Licence to Operate.' Resources Policy 41: 83-90. doi.org/10.1016/j.resourpol.2014.04.002

Rivers, J., 1999. 'Formulating Basic Policy for Community Relations Programs.' Canberra: The Australian National University, Research School of Pacific and Asian Studies, State, Society and Governance in Melanesia Project (Discussion Paper 99/1). 
Skrzypek, E., 2020. Revealing the Invisible Mine: Social Complexities of an Undeveloped Mining Project. New York: Berghahn.

Stead, V.C., 2016. Becoming Landowners: Entanglements of Custom and Modernity in Papua New Guinea and Timor-Leste. Honolulu: University of Hawai' $\mathrm{i}$ Press. doi.org/10.21313/hawaii/9780824856663.001.0001

Strathern, M., 2005. Kinship, Law and the Unexpected: Relatives Are Always a Surprise. Cambridge: Cambridge University Press.

Toft, S. (ed.), 1997. Compensation for Resource Development in Papua New Guinea. Boroko: Law Reform Commission (Monograph 6). Canberra: The Australian National University, National Centre for Development Studies (Pacific Policy Paper 24).

Valenta, R.K., D. Kemp, J.R. Owen, G.D. Corder and E. Lèbre, 2019. 'Re-Thinking Complex Orebodies: Consequences for the Future World Supply of Copper.' Journal of Cleaner Production 220: 816-826. doi.org/ $10.1016 /$ j.jclepro.2019.02.146

Walton, G., 2015. 'Defining Corruption where the State is Weak: The Case of Papua New Guinea.' Journal of Development Studies 51: 15-31. doi.org/ $10.1080 / 00220388.2014 .925541$

Welker, M., 2014. Enacting the Corporation: An American Mining Firm in PostAuthoritarian Indonesia. Berkeley: University of California Press. doi.org/ $10.1525 / 9780520957954$

Wesley-Smith, T., 1990. 'The Politics of Access: Mining Companies, the State, and Landowners in Papua New Guinea.' Political Science 42(2): 1-19. doi.org/ $10.1177 / 003231879004200201$ 
This text is taken from The Absent Presence of the State in LargeScale Resource Extraction Projects, edited by Nicholas Bainton and Emilia E. Skrzypek, published 2021 by ANU Press, The Australian National University, Canberra, Australia.

doi.org/10.22459/AP.2021.02 